\title{
Effects of Acute Normovolemic Anemia on Hemodynamic Parameters and Acid-Base Balance in Dogs
}

\author{
Tatiana Champion, Glaucia Bueno Pereira Neto, and Aparecido Antonio Camacho \\ Department of Animal Surgery and Clinical Sciences, Faculty of Agricultural and Veterinary Sciences (FCAV), \\ São Paulo State University (UNESP), Via de Acesso Professor Paulo Donato Castellane, km 5, 14884-900 Jaboticabal, SP, Brazil \\ Correspondence should be addressed to Tatiana Champion, tatichampion@uol.com.br
}

Received 27 October 2010; Revised 7 January 2011; Accepted 18 February 2011

Academic Editor: Remo G. Lobetti

Copyright ( $\odot 2011$ Tatiana Champion et al. This is an open access article distributed under the Creative Commons Attribution License, which permits unrestricted use, distribution, and reproduction in any medium, provided the original work is properly cited.

\begin{abstract}
The aim of this study was to evaluate the hemodynamic and acid-base status of dogs subjected to acute normovolemic anemia. The dogs $(n=10)$ were evaluated 15 minutes and 24 hours after induction of anemia (hematocrit below $18 \%)$ with blood withdrawal and simultaneously replacement of same volume of Ringer's lactate solution and hydroxyethyl starch-based solution in a $2: 1$ ratio. The cardiac output was measured by Doppler echocardiography and blood pressure by oscillometric device, and posteriorly hemodynamic parameters were calculated. The anemic groups had increase in cardiac index $(P<.05)(3.82 \pm 1.05$ to $5.86 \pm$ 1.49 and $\left.5.81 \pm 1.63 \mathrm{~L} / \mathrm{min} \times \mathrm{m}^{2}\right)$ and decreases $(P<.05)$ in the indices of total peripheral resistance $(6797.81 \pm 3060.22$ to $3220.14 \pm 1275.02$ and $\left.3887.74 \pm 1394.89 \mathrm{dina} \cdot \mathrm{seg} / \mathrm{cm}^{5} \times \mathrm{m}^{2}\right)$ and oxygen delivery $(7942.84 \pm 3344.00$ to $4021.68 \pm 1627.00$ and $\left.4430.82 \pm 1402.61 \mathrm{~mL} / \mathrm{min} \times \mathrm{m}^{2}\right)$, respectively. There were no significant changes in $\mathrm{pH}$, but $\mathrm{PaO}_{2}$ and $\mathrm{SaO}_{2}$ values were increased, and $\mathrm{PaCO}_{2}$ reduced in anemic dogs $(P<.05)$. Therefore, acute normovolemic anemia can create significant hemodynamic changes and despite some hemogasometric changes, there were no changes in the acid-base status in dogs.
\end{abstract}

\section{Introduction}

Acute normovolemic anemia results from the withdrawal of blood and simultaneous replacement with an appropriate volume of colloid and crystalloid fluids to maintain normovolemia [1]. This procedure has been used as a model of anemia in dogs [2-5].

Although acute normovolemic anemia has been used in the therapy of different diseases, including acute ischemic stroke, sudden deafness, and acute pancreatitis in humans [1], the most important indication for this procedure is avoidance of homologous blood transfusion in the perioperative setting $[6,7]$.

During normovolemic anemia, maintenance of adequate tissue oxygenation and aerobic metabolism depend on compensatory mechanisms such as increased cardiac output and increased oxygen extraction, in addition to improvement of blood flow distribution [8]. The reduction in blood viscosity associated with decreased hematocrit can trigger hemodynamic events, since decreased viscosity improves the rheological characteristics of blood and this, in turn, improves indices of afterload, tissue perfusion, and venous return $[1,6-8]$.

Critical hemoglobin values occur when oxygen delivery $\left(\mathrm{DO}_{2}\right)$ decreases below a critical level and the compensatory mechanisms become insufficient, resulting in decreased oxygen consumption $\left(\mathrm{VO}_{2}\right)$ and increased lactate levels [1]. In this setting, in addition to hemodynamic changes, there may be acid-base disturbances related to hemoglobin reduction, since hemoglobin accounts for more than $80 \%$ of the nonbicarbonate buffering capacity of whole blood [9].

Acute normovolemic anemia may be an experimental model of anemia; in addition, the use of this procedure to avoid poorly matched blood transfusion in surgical patients has become more frequent in small animal practice. Therefore, it is important to determine if acute normovolemic anemia can cause changes in noninvasive hemodynamic parameters and acid-base balance in dogs.

Therefore, the purpose of this study was to determine the effects of acute normovolemic anemia on hemodynamic 
parameters and acid-base status in dogs by observing effects on cardiac index (CI), stroke volume index (SVI), total peripheral resistance index (TPRI), left ventricular work index (LVWI), and oxygen delivery index $\left(\mathrm{DO}_{2} \mathrm{I}\right)$, as well as arterial blood gas parameters.

\section{Material and Methods}

The study group comprised ten healthy adult mongrel dogs, seven males and three females, with mean weight of $14.81 \pm$ $1.90 \mathrm{~kg}$. Before the study, blood count, serum chemistry profile (creatinine, alanine aminotransferase, total protein, and albumin), electrocardiography, Doppler echocardiography, and systemic blood pressure measurement were performed.

This study was in accordance with ethical principles in animal experimentation and was reviewed and approved by the Institutional Ethics and Animal Welfare Committee (Protocol no. 018344-07).

Induction of acute normovolemic anemia followed the model previously described $[3,4]$, with objectives to provide low hematocrit values with minimum risks for the dog. For the induction of anemia, approximately 20\% of total circulating blood was removed by jugular venipuncture every 12-24 hours for 3-4 days to obtain a hematocrit below $18 \%$. If the dogs showed mild signs of anemia, the procedure was made in a 24-hour interval, and if the dogs presented severe signs of anemia, they should receive blood transfusion and should be eliminated from this research. The total circulating blood volume of each animal was calculated as eight percent of body weight. Simultaneously with the withdrawal of blood, the animal received the same volume of Ringer's lactate solution and hydroxyethyl starch-based solution (HES $450 / 0.7-6 \%)$ in saline ( $9 \mathrm{mg}$ of $\mathrm{NaCl} / \mathrm{ml})$, in a $2: 1$ ratio to maintain normovolemia.

The animals underwent daily physical examination and cardiovascular assessments (blood pressure and Doppler echocardiography) during evolution of anemia. The hematocrit was measured prior to the next exchange transfusion and after treatment, and at that time it was $18 \%$ or less, and further bleeding was stopped.

Arterial blood gases analysis, blood pressure, and Doppler echocardiography were performed in two stages, 15 minutes after hematocrit fell below $18 \%$ and 24 hours after induction of anemia. After assessment at 24 hours, all dogs received autologous blood transfusion to normalize erythrocyte values.

The acid-base status was evaluated by $\mathrm{pH}, \mathrm{PaCO}_{2}$, $\mathrm{PaO}_{2}$, and $\mathrm{HCO}_{3}{ }^{-}$measurements in an automatic hemogasometer (Hemogasometer Omni C., Roche Diagnostics $\mathrm{GmbH}$, Mannheim, Baden-Wüttenberg, Germany), which also measures arterial oxygen saturation $\left(\mathrm{SaO}_{2}\right)$ and plasma osmolality.

Blood pressure was obtained by averaging five measurements with a noninvasive oscillometric device (Dixtal model DX2710, São Paulo, SP., Brazil) with the dogs positioned in right lateral recumbence and the cuff (width of $40 \%$ of limb circumference) placed on distal forelimb. Cardiac output (CO) was determined by Doppler echocardiography (Doppler ultrasound device, model 300S Pandion,
Pie Medical, Maastricht, Netherlands) and calculated from the integral velocity of aortic flow (FVI), aortic area (A), and heart rate $(\mathrm{HR})$ using the equation $\mathrm{CO}=\mathrm{FVI} \times \mathrm{A}$ $\times$ HR [10]. The aortic FVI was determined in a twodimensional left parasternal projection, in the apical fivechamber view, and the aortic area was measured in a two-dimensional right parasternal view, in the transversal short-axis view of aortic and left atrium, using a $5 \mathrm{mHz}$ probe. The values of FVI, aortic area, and heart rate were obtained by an average of five measurements, and cardiac output was automatically calculated by echocardiographic device.

Stroke volume (SV) was obtained by dividing the cardiac output (CO) by heart rate (HR), according to the formula $\mathrm{SV}=\mathrm{CO}(\mathrm{mL} / \mathrm{min}) / \mathrm{HR}(\mathrm{bpm})[11]$. Left ventricular work (LVW) was the product of mean arterial pressure (MAP) and cardiac output, and the correction factor was 0.0135 $(\mathrm{L} \cdot \mathrm{mmHg}$ to $\mathrm{kg} \cdot \mathrm{m})$, according to the formula $\mathrm{LVW}=\mathrm{MAP}$ $(\mathrm{mm} \cdot \mathrm{Hg}) \times \mathrm{DC}(\mathrm{L} / \mathrm{min}) \times 0.0135[12]$.

Total peripheral resistance (TPR) was obtained by dividing the mean arterial pressure by cardiac output multiplied by the correction factor 79.9 ( $\mathrm{mmHg} \cdot \mathrm{min} / \mathrm{L}$ to dina.seg $\left./ \mathrm{cm}^{5}\right)$, according to the formula TPR $=[\mathrm{MAP}$ $(\mathrm{mm} \cdot \mathrm{Hg}) / \mathrm{DC}(\mathrm{L} / \mathrm{min})] \times 79.9$ [12]. Finally, oxygen arterial content $\left(\mathrm{CaO}_{2}\right)$ was calculated by the equation $(1.34 \times$ hemoglobin $\left.\times \mathrm{SaO}_{2}\right)+\left(\mathrm{PaO}_{2} \times 0.003\right)[11]$.

Hemodynamic parameters such as cardiac output, stroke volume, systemic vascular resistance, left ventricular work, and oxygen delivery were calculated and subsequently normalized by body surface area $\left(\mathrm{m}^{2}\right)$ to obtain indices that minimize the effect of weight difference.

The data obtained in the experiment were statistically analyzed by the computer program ProcGLM Statistical Analysis System (SAS), using analysis of variance (ANOVA), followed by Tukey's test to compare the means of groups over time with the level of significance at $5 \%$.

\section{Results}

Three dogs presented weakness and drowsiness at physical exam, and no animal showed signs of congestive heart failure, collapse, or other signs of anemia.

The mean values of systolic, mean, and diastolic arterial blood pressures were significantly decreased when the animals were evaluated immediately after hematocrit fell below $18 \%$. Evaluation after 24 hours of anemia only revealed a significant reduction in mean diastolic blood pressure. The means \pm standard deviations of arterial blood pressures measured over time (basal, 15 minutes, and 24 hours after the anemia) are described in Table 1.

The cardiac output obtained by Doppler echocardiography was divided by body surface area to obtain the cardiac index. The mean cardiac index increased significantly $(P=$ .0121 ) in both evaluations when normovolemic anemia was compared to mean basal values. The mean heart rate before induction of anemia was significantly $(P=.009)$ different (106 \pm 33 beats/minute) from the heart rate after anemia ( $131 \pm 32$ beats/minute 15 minutes after induction of anemia and $125 \pm 20$ beats/min 24 hours after induction of anemia). 
TABLE 1: Mean values \pm standard deviations of hemodynamic parameters obtained from dogs $(n=10)$ before (Basal) and 15 minutes and 24 hours after induction of acute normovolemic anemia.

\begin{tabular}{lccc}
\hline Hemodynamic parameters & Basal & 15 minutes & 24 hours \\
\hline SBP $(\mathrm{mmHg})$ & $142 \pm 05^{\mathrm{a}}$ & $124 \pm 17^{\mathrm{b}}$ & $142 \pm 07^{\mathrm{a}}$ \\
MBP $(\mathrm{mmHg})$ & $107 \pm 10^{\mathrm{a}}$ & $79 \pm 14^{\mathrm{b}}$ & $95 \pm 10^{\mathrm{a}}$ \\
DBP $(\mathrm{mmHg})$ & $88 \pm 10^{\mathrm{a}}$ & $59 \pm 12^{\mathrm{b}}$ & $71 \pm 10^{\mathrm{c}}$ \\
CI $\left(\mathrm{L} / \mathrm{min} \cdot \mathrm{m}^{2}\right)$ & $3,82 \pm 1,05^{\mathrm{b}}$ & $5,86 \pm 1,49^{\mathrm{a}}$ & $5,81 \pm 1,63^{\mathrm{a}}$ \\
SVI $\left(\mathrm{mL} / \mathrm{beats} \cdot \mathrm{m}^{2}\right)$ & $39,61 \pm 15,30^{\mathrm{a}}$ & $45,82 \pm 12,49^{\mathrm{a}}$ & $46,38 \pm 9,64^{\mathrm{a}}$ \\
TPRI $\left(\right.$ dina.seg $\left./ \mathrm{cm}^{5} \cdot \mathrm{m}^{2}\right)$ & $6797,81 \pm 3060,22^{\mathrm{a}}$ & $3220,14 \pm 1275,02^{\mathrm{b}}$ & $3887,74 \pm 1394,89^{\mathrm{b}}$ \\
LVWI $\left(\mathrm{Kg} / \mathrm{m} / \mathrm{min} \cdot \mathrm{m}^{2}\right)$ & $5,55 \pm 1,74^{\mathrm{a}}$ & $6,18 \pm 1,53^{\mathrm{a}}$ & $7,46 \pm 2,31^{\mathrm{a}}$ \\
$\mathrm{DO}_{2} \mathrm{I}\left(\mathrm{mL} / \mathrm{min} \cdot \mathrm{m}^{2}\right)$ & $79,43 \pm 33,44^{\mathrm{a}}$ & $40,22 \pm 16,27^{\mathrm{b}}$ & $44,31 \pm 14,03^{\mathrm{b}}$ \\
\hline
\end{tabular}

Letters indicate significant differences $(P<.05)$. SBP: systolic blood pressure; MBP: mean blood pressure; DMP: diastolic blood pressure; CI: cardiac index; SVI: stroke volume index; TPRI: total peripheral resistance index; LVWI: left ventricular work index; $\mathrm{DO}_{2} \mathrm{I}$ : oxygen delivery index.

The mean cardiac index, stroke volume index, total peripheral resistance index, left ventricular work index, and oxygen delivery index are also represented in Table 1.

The mean total peripheral resistance index was significantly lower in the anemic groups compared to baseline $(P=$ .0007). The mean stroke volume index and left ventricular work index showed no statistical differences between all groups. The mean values of oxygen delivery index $\left(\mathrm{DO}_{2} \mathrm{I}\right)$ of anemic groups were lower than baseline $(P=.0026)$.

The anemia induced was severe, the hemoglobin of anemic dogs was $5,11 \pm 1,05 \mathrm{~g} / \mathrm{dL}$ ( 15 minutes after anemia induction) and $6,01 \pm 0,73 \mathrm{~g} / \mathrm{dL}$ (24 hours after anemia induction), compared to the mean basal values of 15,63 $\pm 2,81 \mathrm{~g} / \mathrm{dl}$. The oxygen content $\left(\mathrm{CaO}_{2}\right)$ values \pm standard deviation were $20,18 \pm 3,61 \mathrm{ml} \mathrm{O} / 100 \mathrm{ml}$ (basal), 6,80 \pm $1,33 \mathrm{ml} \mathrm{O}_{2} / 100 \mathrm{ml}$, and $7,87 \pm 0,97 \mathrm{ml} \mathrm{O}_{2} / 100 \mathrm{ml}(15$ and 24 hours after anemia, respectively).

Regarding arterial blood gas evaluations, despite the decrease $(P=.026)$ of mean plasma concentration of bicarbonate $\left(\mathrm{HCO}_{3}{ }^{-}\right)$observed after 15 minutes, there was no significant variation in mean arterial $\mathrm{pH}$. There was increase of mean base excess from $-0,97 \pm 2,9$ (basal) to $-5,8$ $\pm 1,5$ (15 minutes after anemia induction). The mean partial pressure of oxygen in arterial blood $\left(\mathrm{PaO}_{2}\right)$, increased $(P=$ $.026)$ in dogs with acute normovolemic anemia compared to the average baseline. However, the mean partial pressure of carbon dioxide in arterial blood $\left(\mathrm{PaCO}_{2}\right)$, decreased at 15 minutes $(P=.026)$.

Furthermore, the mean values of oxyhemoglobin saturation $\left(\mathrm{SaO}_{2}\right)$ of anemic dogs were increased compared to baseline $(P=.015)$. There were no significant changes in mean plasma osmolality of dogs with acute normovolemic anemia.

The means \pm standard deviations of arterial blood gas and plasma osmolality parameters of dogs submitted to acute normovolemic anemia are shown in Table 2.

\section{Discussion}

This experimental model of acute normovolemic anemia is similar to the hemodilution protocol proposed for humans and animals $[1,6,13]$. The protocol was used to evaluate dogs with anemia without hypovolemia, anesthesia, or other
TABle 2: Mean values \pm standard deviations of arterial blood gas parameters and serum osmolality of dogs $(n=10)$ before (Basal) and 15 minutes and 24 hours after induction of acute normovolemic anemia.

\begin{tabular}{lccc}
\hline Parameter & Basal & 15 minutes & 24 hours \\
\hline $\mathrm{pH}$ & $7,41 \pm 0,04^{\mathrm{a}}$ & $7,43 \pm 0,04^{\mathrm{a}}$ & $7,43 \pm 0,03^{\mathrm{a}}$ \\
$\mathrm{PaO}_{2}(\mathrm{mmHg})$ & $92,2 \pm 5,9^{\mathrm{b}}$ & $103,1 \pm 7,2^{\mathrm{a}}$ & $101,8 \pm 8,5^{\mathrm{a}}$ \\
$\mathrm{PaCO}_{2}(\mathrm{mmHg})$ & $36,1 \pm 4,9^{\mathrm{a}}$ & $28,3 \pm 3,3^{\mathrm{b}}$ & $32,9 \pm 2,2^{\mathrm{a}}$ \\
$\mathrm{HCO}_{3}{ }^{-}(\mathrm{mmol} / \mathrm{L})$ & $22,2 \pm 3,0^{\mathrm{a}}$ & $18,0 \pm 1,2^{\mathrm{b}}$ & $21,0 \pm 2,5^{\mathrm{a}}$ \\
$\mathrm{SaO}_{2}(\%)$ & $96,2 \pm 1,0^{\mathrm{b}}$ & $97,4 \pm 0,7^{\mathrm{a}}$ & $97,3 \pm 0,6^{\mathrm{a}}$ \\
Osmolality $(\mathrm{mOsm} / \mathrm{kg})^{2} 296 \pm 08^{\mathrm{a}}$ & $292 \pm 07^{\mathrm{a}}$ & $292 \pm 07^{\mathrm{a}}$ \\
\hline
\end{tabular}

Letters indicate significant differences $(P<.05)$.

conditions that could interfere with hemodynamic and cardiac function. This model proved to be viable, and the side effects observed, including weakness and drowsiness, were minimal. No animal showed signs of congestive heart failure or collapse, similar to the findings reported in an experimental model of acute normovolemic anemia [4].

Decreases in systolic, diastolic, and mean blood pressure observed 15 minutes after anemia induction can be explained by reduction of blood viscosity and by vasodilatation to compensatory changes which attempt to prevent tissue hypoxia $[6,14]$.

Decreased blood pressure was also reported in studies on acute $[8,13,15]$ and chronic anemia $[16,17]$. Although some authors are uncertain about the occurrence of vasodilatation during hemodilution [18], vasodilatation mediated by nitric oxide $[19,20]$ and by vasoactive prostanoids such as prostaglandin (PGI2) [18] has been implicated in the compensatory response to acute normovolemic anemia. Nitric oxide is an important chemical compound derived from the vascular endothelium with an important role in regulating vascular tone, and its involvement in cardiovascular physiology is well established $[18,19]$. The local blood flow conditions modulate the production of vasoactive substances by endothelial cells, and the nitric oxide synthesis is dependent on shear-stress magnitude [21]. Shear stress is a consequence of the flow configuration and local blood viscosity although it is also necessary to consider that the infusion of colloids in hemodilution changes the viscosity 
in microvascular space and enhances the syntheses of nitric oxide [22].

In this study, anemic dogs had increased cardiac index and decreased peripheral vascular resistance index. As blood pressure is the product of cardiac output and peripheral vascular resistance $[19,23]$, this relationship can explain the absence of blood pressure changes, as observed in systolic and mean systemic pressures in the group evaluated after 24 hours of anemia induction. The analysis of blood pressure in dogs is of fundamental importance because they were conscious and unmedicated, and most blood pressure data during acute normovolemic anemia refers to animals under anesthesia or sedation, which may affect this parameter [4].

Deeply anesthetized dogs did not present significantly changes on heart rate, mean blood pressure, and cardiac index, differently from dogs with mild anesthesia or conscious; therefore, it is important to carefully titrate the level of anesthesia and monitoring cardiovascular and hemodynamic response in patients undergoing hemodilution [24]. Another study revealed no changes in heart rate in anesthetized dogs submitted to hemodilution, and the increase in cardiac output was due to increase of systolic volume [6].

Moreover, it was demonstrated that general anesthesia influences compensatory mechanisms during acute normovolemic anemia, since increasing anesthetic depth progressively blunts the compensatory increase in cardiac output [24]. Therefore, the rise in cardiac output is significantly smaller in anesthetized than in conscious patients [25]. The lack of heart rate increase during acute normovolemic hemodilution in anesthetized patients may be the result of a depression of the autonomic nervous system by anesthetics, especially inhalants, or by central vagal stimulation caused by opioids $[1,25]$.

Adequate tissue oxygenation during acute normovolemic anemia is maintained by both an increase in cardiac output and an increase in tissue oxygen extraction. The increase in cardiac output is related to the reduction in blood viscosity resulting in increased venous return, followed by decreased ventricular afterload and peripheral vascular resistance, as well as an increased sympathetic stimulation of the heart, increasing the heart rate and myocardial contractility $[8,26]$. Thus, increases in cardiac output and cardiac index are closely related to the hemodynamic compensatory anemic state $[6,8,14,26]$. This study supports a decrease in afterload by significantly reducing the mean arterial blood pressure and the probable effects on reducing ventricular pressure in anemic dogs. However, the left ventricular work index showed only a tendency to rise in anemic animals. This result can be explained by an increase in cardiac output to overcome the fall in mean arterial pressure in these dogs, since both are directly proportional to ventricular work index [12].

Cardiac output is the product of heart rate and stroke volume [23], and it is directly related to these indices, as increases in heart rate and stroke volume lead to increased cardiac output. In anesthetized patients, the increase in cardiac output is due to an increase in stroke volume, whereas increases in stroke volume and heart rate are observed in conscious persons undergoing acute normovolemic anemia [25]. In the present investigation, the significant increase in cardiac index may be explained by stimulation of the autonomic nervous system and consequent increase in heart rate, as there was no significant difference in mean values of stroke volume index. Previous studies of acute normovolemic anemia also showed an increase in cardiac output as a compensatory response $[1,8,13,15,17,19,22$, 27].

The significantly reduced oxygen delivery index $\left(\mathrm{DO}_{2} \mathrm{I}\right)$ in anemic dogs caused decreased tissue oxygenation, a condition that can be observed in extreme hemodilution $[1,8]$. In this context, besides the increase in cardiac output, increased oxygen extraction generally maintains adequate myocardial oxygen consumption. In acute normovolemic anemia, redistribution of microvascular blood flow and adjustments such as increasing the speed of red cells occur, associated to reduced blood viscosity. The influence of hematocrit upon blood viscosity is known and besides the effects of red cells concentrations, the blood viscosity varies in function of shearing stress developed within the fluid and the rate at which these forces are distributed between the adjacent fluids. Therefore, blood is considered a Newtonian fluid, assuming in this way that the ratio of shear stress to shear rate was constant and directly related to blood flow [28]. Although blood viscosity was not measured in the dogs in our study, hemodilution with HAS replacement method of inducing normovolemic anemia would alter blood viscosity [22].

No acid-base disturbances were verified in the anemic dogs of this experiment. Although the $\mathrm{pH}$ values were unchanged and within normal parameters, plasma levels of bicarbonate were significantly reduced and base excess increased. This result can be explained by a metabolic imbalance and increased consumption of bicarbonate to maintain the $\mathrm{pH}$, since its effect on blood buffer is higher than that of hemoglobin [9]. In this study, it would be of great value the measurement of lactate to rule out lactic acidosis.

These results are similar to those described by other studies, which reported a lower incidence of metabolic acidosis during hemodilution, since acute normovolemic anemia improves tissue perfusion [13]. However, a study determined a positive correlation between degree of anemia and decreased $\mathrm{pH}$ in human fetus with severe anemia [29]. Extremely severe anemia (hematocrit less than 10\%) and hypoxemia $\left(\mathrm{PaO}_{2}\right.$ smaller than $\left.30 \mathrm{mmHg}\right)$ are associated with lactic acidosis type A (hypoxic), in which the function of mitochondria is maintained, but the oxygen supply to tissues is inadequate [9]. For this reason, the procedure of acute normovolemic anemia with severe fall in hematocrit is not safe and is not recommended.

Finally, the increase in the levels of $\mathrm{PaO}_{2}$ and fall of $\mathrm{PaCO}_{2}$ in anemic dogs could be associated with stress, since dogs were awake during the procedure of acute normovolemia. Other evidence is that anemia may affect $\mathrm{CO}_{2}$ homeostasis, since without changes in metabolism or blood flow, and assuming a constant $\mathrm{PaCO}_{2}$, brain tissue $\mathrm{PaCO}_{2}$ would rise approximately six Torr with a fall in 
hematocrit from 42 to $15 \%$ [30]. Other factors that may play a role in compensation for anemia include increase in ventilation, contributing for the gas changes observed in hemodilution [31].

\section{Conclusions}

Based on the results obtained with this study, it was concluded that severe acute normovolemic anemia may trigger compensatory hemodynamic events such as increased cardiac index, decreased peripheral vascular resistance, and reduced mean blood pressure. The increased cardiac index prevents the decrease in oxygen delivery that would be caused by the decrease in oxygen content. There were no changes in stroke volume and left ventricular work indices. Induction of acute normovolemic anemia does not cause disturbances in plasma osmolality or imbalance in the acid-base status of dogs. Although clinical signs of anemia were minimal, severe acute hemodilution is associated to hemodynamic changes that could not be desirable and safe. Clinical signs of inadequate tissue oxygenation during anemia are nonspecific, and they are usually absent in sedated or anesthetized patients. Because anemia can cause many hemodynamic changes, the decision to transfuse is individual and depends on hemodynamic consequences for the patient, taking into account not only the hemoglobin concentration.

\section{Acknowledgment}

Financial support was provided by CAPES (Coordenação de Aperfeiçoamento de Pessoal de Nível Superior).

\section{References}

[1] M. Jamnicki, R. Kocian, P. Van Der Linden, M. Zaugg, and D. R. Spahn, "Acute normovolemic hemodilution: physiology, limitations and clinical use," Journal of Cardiothoracic and Vascular Anesthesia, vol. 17, no. 6, pp. 747-754, 2003.

[2] G. Kouraklis, P. Karayannacos, M. Sechas et al., "The influence of hemodilution on left ventricular function," International Angiology, vol. 9, no. 1, pp. 38-42, 1990.

[3] L. M. Koma, T. C. Spotswood, R. M. Kirberger, and P. J. Becker, "Influence of normovolemic anemia on Doppler characteristics of the abdominal aorta and splanchnic in Beagles," American Journal of Veterinary Research, vol. 66, no. 2, pp. 187-195, 2005.

[4] T. C. Spotswood, R. M. Kirberger, L. M. P. K. Koma, F. Reyers, and L. Van Der Merwe, "A canine model of normovolaemic acute anaemia," Onderstepoort Journal of Veterinary Research, vol. 72, no. 2, pp. 135-143, 2005.

[5] L. M. Koma, R. M. Kirberger, and L. Scholtz, "Doppler ultrasonographic changes in the canine kidney during normovolaemic anaemia," Research in Veterinary Science, vol. 80, no. 1, pp. 96-102, 2006.

[6] O. P. Habler, M. S. Kleen, A. H. Podtschaske et al., "The effect of acute normovolemic hemodilution (ANH) on myocardial contractility in anesthetized dogs," Anesthesia and Analgesia, vol. 83, no. 3, pp. 451-458, 1996.

[7] M. Licker, J. Sierra, A. Kalangos, A. Panos, J. Diaper, and C. Ellenberger, "Cardioprotective effects of acute normovolemic hemodilution in patients with severe aortic stenosis undergoing valve replacement," Transfusion, vol. 47, no. 2, pp. 341-350, 2007.

[8] M. Licker, C. Ellenberger, N. Murith et al., "Cardiovascular response to acute normovolaemic haemodilution in patients with severe aortic stenosis: assessment with transoesophageal echocardiography," Anaesthesia, vol. 59, no. 12, pp. 11701177, 2004.

[9] S. P. DiBartola, Anormalidades de Fluidos, Eletrólitos e Equilíbrio Ácido-Cásico na Clínica de Pequenos Animais, Roca, São Paulo, Brazil, 3rd edition, 2007.

[10] H. Ihlen, J. P. Amlie, and J. Dale, "Determination of cardiac output by Doppler echocardiography," British Heart Journal, vol. 51, no. 1, pp. 54-60, 1984.

[11] M. Mellema, "Cardiac output, wedge pressure, and oxygen delivery," Veterinary Clinics of North America, vol. 31, no. 6, pp. 1175-1205, 2001.

[12] A. Valverde, D. H. Dyson, J. R. Cockshutt, W. N. McDonell, and A. E. Valliant, "Comparison of the hemodynamic effects of halothane alone and halothane combined with epidurally administered morphine for anesthesia in ventilated dogs," American Journal of Veterinary Research, vol. 52, no. 3, pp. 505-509, 1991.

[13] A. O. Fraga, D. T. Fantoni, D. A. Otsuki, C. A. Pasqualucci, M. C. D. Abduch, and J. O. Costa Auler, "Evidence for myocardial defects under extreme acute normovolemic hemodilution with hydroxyethyl starch and lactated ringer's solution," Shock, vol. 24, no. 4, pp. 388-395, 2005.

[14] W. Yaphé, S. Giovengo, and S. Moise, "Severe cardiomegaly secondary to anemia in a kitten," Journal of the American Veterinary Medical Association, vol. 202, no. 6, pp. 961-964, 1993.

[15] O. Habler et al., "Akute normovolämische Hämodilution (AHN): effekte der ANH auf die diastoliche function des linken ventrileks," Anaesthesist, vol. 49, no. 5, pp. 939-948, 2000.

[16] V. K. Bahl, O. P. Malhotra, D. Kumar et al., "Noninvasive assessment of systolic and diastolic left ventricular function in patients with chronic severe anemia: a combined M-mode, two-dimensional, and Doppler echocardiographic study," American Heart Journal, vol. 124, no. 6, pp. 1516-1523, 1992.

[17] A. Aessopos, S. Deftereos, D. Farmakis et al., "Cardiovascular adaptation to chronic anemia in the elderly: an echocardiographic study," Clinical and Investigative Medicine, vol. 27, no. 5, pp. 265-273, 2004.

[18] Y. Hirose, H. Kimura, H. Kitahata, S. Kawahito, S. Oshita, and Y. Hirose, "Nitric oxide does not play a major role in the regulation of systemic hemodynamic responses to acute normovolemic hemodilution," Acta Anaesthesiologica Scandinavica, vol. 44, no. 1, pp. 96-100, 2000.

[19] D. N. Doss, F. G. Estafanous, C. M. Ferrario, J. M. Brum, and P. A. Murray, "Mechanism of systemic vasodilation during normovolemic hemodilution," Anesthesia and Analgesia, vol. 81, no. 1, pp. 30-34, 1995.

[20] F. Metivier, S. J. Marchais, A. P. Guerin, B. Pannier, and G. M. London, "Pathophysiology of anaemia: focus on the heart and blood vessels," Nephrology Dialysis Transplantation, vol. 15, no. 3, pp. 14-18, 2000.

[21] M. Noris, M. Morigi, R. Donadelli et al., "Nitric oxide synthesis by cultured endothelial cells is modulated by flow conditions," Circulation Research, vol. 76, no. 4, pp. 536-543, 1995.

[22] A. G. Tsai, C. Acero, P. R. Nance et al., "Elevated plasma viscosity in extreme hemodilution increases perivascular nitric 
oxide concentration and microvascular perfusion," American Journal of Physiology, vol. 288, no. 4, pp. H1730-H1739, 2005.

[23] A. A. Camacho, "Aspectos clínicos e fisiopatológicos da insuficiência cardíaca congestiva," in Afecções Cardiovasculares em Pequenos Animais, G. C. Belerenian, C. J. Mucha, and A. A. Camacho, Eds., pp. 72-77, InterBook, São Caetano do Sul, Brazil, 1st edition, 2003.

[24] P. Van der Linden, S. De Hert, N. Mathieu et al., "Tolerance to acute isovolemic hemodilution: effect of anesthetic depth," Anesthesiology, vol. 99, no. 1, pp. 97-104, 2003.

[25] B. E. Ickx, M. Rigolet, and P. J. Van Der Linden, "Cardiovascular and metabolic response to acute normovolemic anemia: effects of anesthesia," Anesthesiology, vol. 93, no. 4, pp. 1011$1016,2000$.

[26] J. Sottiaux, "Cardiovascular effects of anaemia in the cat. An echocardiographic study," in Proceedings of the 29th World Small Animal Veterinary Congress, p. 09, Rhodes, Greece, 2004.

[27] J. Nozaki, H. Kitahata, K. Tanaka, S. Kawahito, and S. Oshita, "The effects of acute normovolemic hemodilution on left ventricular systolic and diastolic function in the absence or presence of $\beta$-adrenergic blockade in dogs," Anesthesia and Analgesia, vol. 94, no. 5, pp. 1120-1126, 2002.

[28] R. E. Wells and E. W. Merrill, "Influence of flow properties of blood upon viscosity-hematocrit relationships," The Journal of Clinical Investigation, vol. 41, no. 8, pp. 1591-1598, 1962.

[29] F. P. Vandenbussche, I. Van Kamp, D. Oepkes, J. Hermans, J. B. Gravenhorst, and H. H. H. Kanhai, "Blood gas and $\mathrm{pH}$ in the human fetus with severe anemia," Fetal Diagnosis and Therapy, vol. 13, no. 2, pp. 115-122, 1998.

[30] R. S. Schacterle, R. J. Ribando, and J. M. Adams, "A model of brain arteriolar oxygen and carbon dioxide transport during anemia," Journal of Cerebral Blood Flow and Metabolism, vol. 13, no. 5, pp. 872-880, 1993.

[31] S. Deem, M. K. Alberts, M. J. Bishop, A. Bidani, and E. R. Swenson, " $\mathrm{CO}_{2}$ transport in normovolemic anemia: complete compensation and stability of blood $\mathrm{CO}_{2}$ tensions," Journal of Applied Physiology, vol. 83, no. 1, pp. 240-246, 1997. 

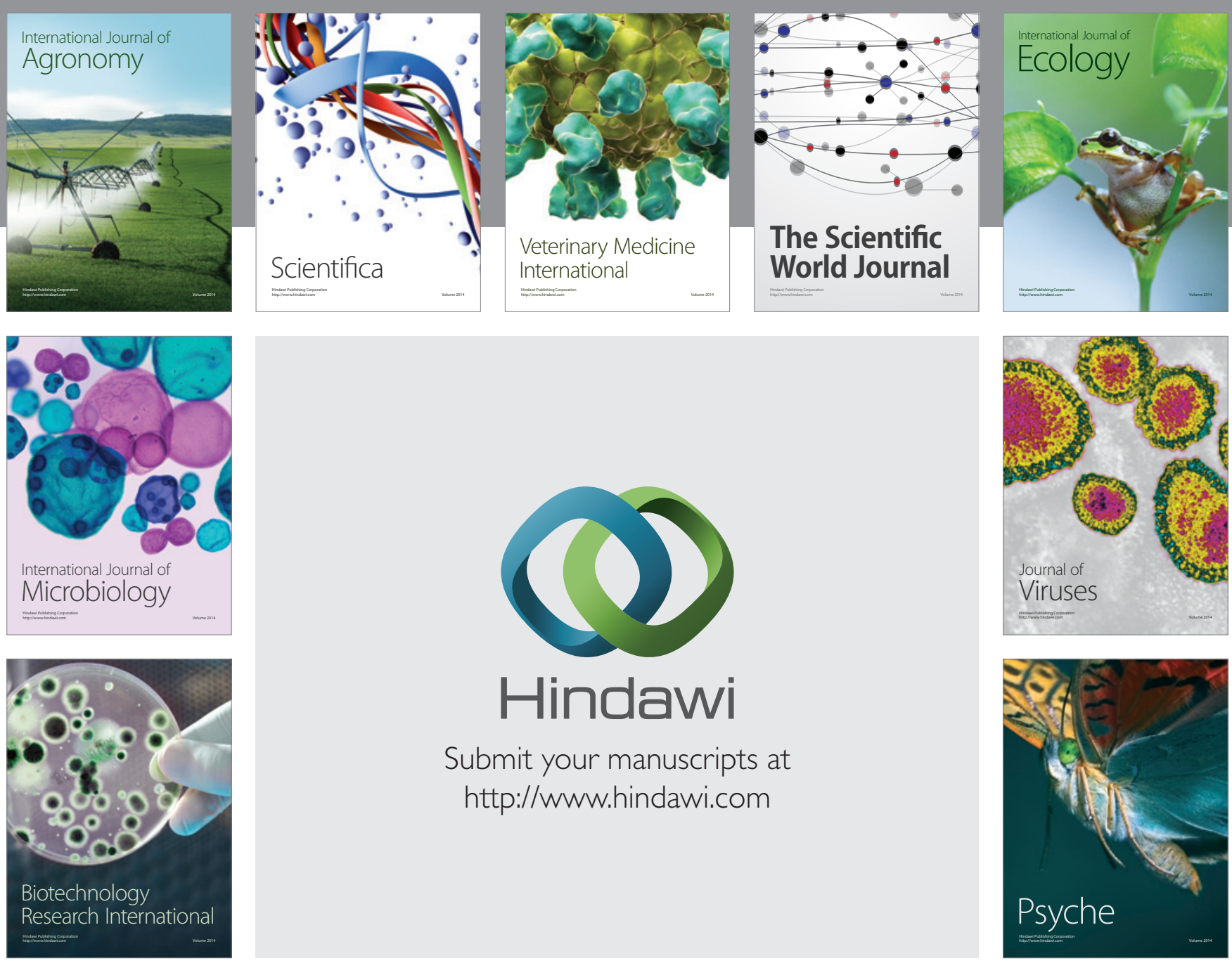

Submit your manuscripts at

http://www.hindawi.com
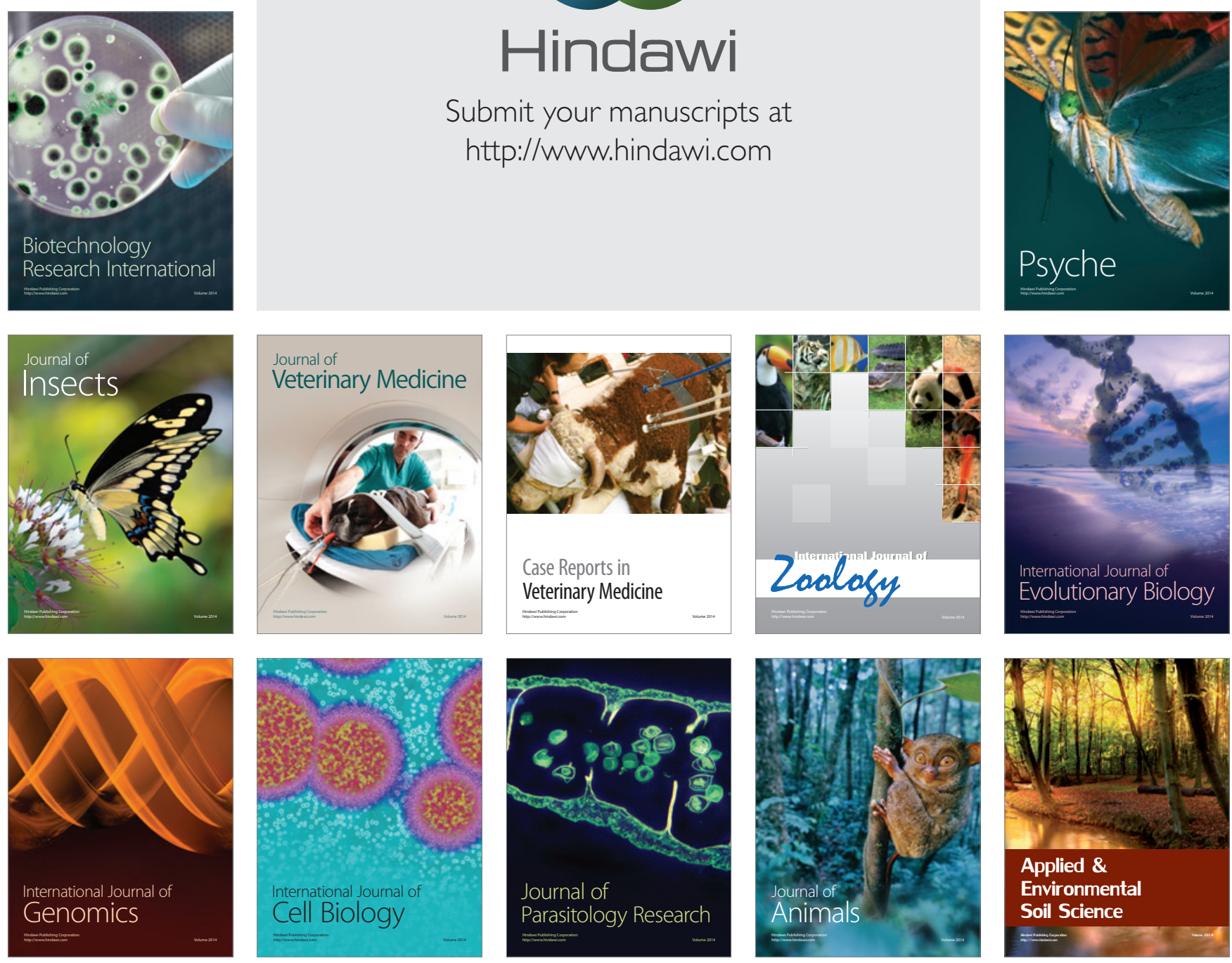